DPST -87-820

\title{
SUMMARY OF I-129 MEASUREMENTS IN GROUND AND SURFACE WATERS (U)
}

by

M. V. Kantelo

WSRC Contact

W. H. Carlton

Environmental Technology

Savannah River Site

Aiken, South Carolina 29808

This is a Technical Report for OSTI and the general public

This paper was prepared in connection with work done under Contract No. DE-AC09-76SR00001 with the U.S. Department of Energy. By acceptance of this paper, the publisher and/or recipient acknowledges the U.S. Government's right to retain a nonexclusive, royalty-free license in and to any copyright covering this paper, along with the right to reproduce and to authorize others to reproduce all or part of the copyrighted paper. 


\section{DISCLAIMER}

This report was prepared as an account of work sponsored by an agency of the United States Government. Neither the United States Government nor any agency thereof, nor any of their employees, makes any warranty, express or implied, or assumes any legal liability or responsibility for the accuracy, completeness, or usefulness of any information, apparatus, product, or process disclosed, or represents that its use would not infringe privately owned rights. Reference herein to any specific commercial product, process, or service by the trade name, trademark, manufacturer, or otherwise, does not necessarily constitute or imply its endorsement, recommendation, or favoring by the United States Government or any agency thereof. The views and opinions of authors expressed herein do not necessarily state or reflect those of the United States Government or any agency thereof. 
TÉCHIVICAL DIVISION

\section{SAVANNAH RIVER LABORATORY}

$\underline{M} M \underline{Q} Q \underline{N} \underline{N} \underline{U}$ keywords:

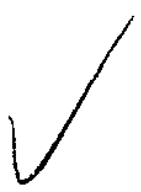

lodine-129

Grourduste:

Surface water

DPST $-87-820$

cc: 3.A. Porter, 703-A

J.S Roberts, 703-A

C.B. Bennett, 703-A

C.R. Sherman, 703-A

J.L. Steele, 703-A

W.C. Reinig, 703-A

R.L. Kump, 735-A

O. B. Wheat, 703-H

J.V. Odum, 703-H

H.D. Harmon, 773-A

J.C. Corey, $773-A$

D.E. Gordon, 773-42A

A.L. Boni, 773-A

R.W. Benjamin, 773-A

W.L. Marter; 773-42A

W.L. McDowe I I, 735-A

E.L. Wiltite, $773-43 \mathrm{~A}$

SRL Recoros (4), 773-A

November 17,1987

To: R.W.Taylor

From: M.V. Kantelo MPPR

Reference: DOE-SR 1 tr to J.A. Porter, dated 11-4-87

SUMMARY OF I-129 MEASUREMENTS IN GROUND AND SURFACE WATERS

\section{INTRODUCTION AND SUMMARY}

The iodine-129 content of groundwater and surface water at on-plant and off-plant locations ( $F$ igure 1 ) has been determined at irregular intervals since 1970 using neutron activation analysis. I-129 was detected in groundwater near the Burial Fround and near the seepage basins of the Separations Areas. For reference, I-129 concentratiors in the groundwater can be compared to the EPA drinking water standard. At a few locations the concentrations exceeded both the existing and pending EPA drinking water standard. In surface water, Four Mile Creek was the only SRP stream found to transport significant i-127 to the Savaririat. River. Dilution by C-Reatzor discherge and the Savarinats River reduced the off-plant I-129 concentrations in river water to less than $1 \%$ of the existing EPA drinking water standard and less than $0.01 \%$ of the pending EPA drinking water standard. 
Water in the vicinity of known sources of I-l29 has been sampled as follows:

o Burial Ground Wells

- Separations Areas

- F-Area effluent feeding Four Mile Creek.

- seepage basins

- wells between seepage basins and outcrop springs

- outcrop springs fesding Four Mile Creek

o SPP Streams Feeding Savannah River

- Four Mile Creek

- other streams

o Savanriah River

Results of I-129 measurements for each of the above categories are summarized in this memo. Otserved concentrations of I-129 in the gioundwater of the SRP site primarily reflect mabile forms of jodine turied in the Burial Ground and discharged to the seepage basins in the Separations Areas. Groundwater concentrations at some locatiors sigrificantly exceed the existing EPA drinking water standard. Some even exceed the less restrictive revised EPA standard which is pending final approval.

The groundwater in which I-129 has been detected becomes surface water at Four Mile Creek. Further dilution by mixirig with the discharge from C-Reactor and with the Savannah River results in off-plant river water concentrations that are less then $1 \%$ of the existing EPA drinking water standard and less than $0.01 \%$ of the pendirg EPA stariard. The pendirg EPA drinking water standard is 100 PCi L. It will replace tre existing EPA standard of $1 \mathrm{pCi} / \mathrm{l}$. The feriding standard is based on ICPP jo dose methodology which DOE has directed to be used at its facilities.

In this summary, concentrations of I-129 are tabulated together with the statistical one standard deviation uncertajnties in the measurements. (For some historical results no statistical uricertainty was found.) Corresforiding stable iodine measurement results are available but were not requested in the reference letter. Stable iodine values are important in calculating the radiation dose due to $1-129$.

The orly active sampling program for I-129 in ground or surface water is the quarterly sampling of Savanhah piver water upstream end donnistream of SRP. This program was reactivated in 1786 after five years of dormancy. Analysis of samples collected since 1986 is still in progiess. Sampling of water at the two water treatment plants near Savanriah is plannred for this fiscal Year. 


\section{DISCUSSION}

\section{Burial Ground Wells}

Analyses of certain well waters in the Burial Ground System (Figure 2) were provided to S.B. Oblath as part of a compretiensive study of the Burial Ground in the mid-1980s. The results were published by Oblath as DPST-Bb-278. This study found that I-i29 leached from the Eurial Grourd is nobile. The maximum concentration observed was $12 \mathrm{pCi} / \mathrm{L}$ in August 1983. rwo earlier measurements of this firticular well ivater revealed lower concentrations. Based on this limited sampling, I-129 conceitrations appeared to be increasing with time. Pesults extracted from DPST-86-278 are presented in..Table I.

In 1979 and 1980 water from two wells at the southwest corner of thie Burial Ground (Figure 2 ) was analyzed. Results are presented in Table I. Even though the location of the wells is near the tritium plume from the Burial Ground, the observed I-120 concentrations are low. This is presumebly due to the weils rot beirig deep enough to intercept the plume.

\section{Separations Areas}

F-Area Effluent Feeding Four Mile Creek

The effluent stream from F-Area that feeds Four Mile Creek was studied in 19,79 and 1980 . Results are presented in Table II. Coricentretions were 0.06 pCill ar less. At this level, the effluent stream is not a significant source of $1-129$.

Seepage Basins

Monthly giab samples of water ir. $F$ basin 3 and in $H$ basin 4 were collected in 1977 and 1978. Each of these basins is the terminal basin in a seilies of progressively lerger basins (Figures 3 end 4 ). Concentrations, which ranged from 15 to $300 \mathrm{pCi} / \mathrm{L}$, are presented in Table III. Gererally, the $H$ basin concentrations were lower theri those in F basin ty a factor of ebout 5 . Wittin each basin, concentration variations are attributed to rainfall and to varying oferatiorial conditions in Separations.

Hel Is BetweEn SeEpage Basins and Uutciop Springs

li August $157 \%$ five H-Area wells Mפie sampled at a depth of 35 feet, aid four F-Area wells vere sampled at depths from 45 to bo feet (FigurEs 3 and 4 ). Results for $i-129$ are presented in 
Table IV. Concentrations ranged from $0.1 \mathrm{pCi} / \mathrm{L}$ to $300 \mathrm{pCi} / \mathrm{L}$ and correlated with tritium concentrations. This indicated that a mobile alquaus. form of iodine was present.

In 1980 water from one H-Area well (designated BG -10) inside the fence at $H$ basin 4 was analyzed. The value of 63 pCill was the greatest concentration observed in H basin wells.

Dutcrop Springs Feeding Four Mile Creek

A grab sample of one of the groundwater outcrop springs in the vicinity of $F$-Arse seepage basins was collected on a one-time basis in fugust 1977 . The $I-129$ concentration of $294 \pm 6 \mathrm{pCi} / \mathrm{L}$ is corisisterit with the moximum concentrations observed in basin water and well water.

\section{SRP Streams Feeding the Savannah River}

Four Mile Creek

Grab samples of creek water have been intermittently sampled since 1973. In Table $V$, results are presented by location upstream and downstream of the groundwater outcrops from F-Area seepage basins. Upstream concentrations of 1 pCi/L or $335 s$ were measured at various locations between Road 4 and the F-Area outcrops. At these locations, the only likely significant source of I-129 is the outcrop springs from H-Area seepage basins.

Further downstream, below the outcrops from F-Area, concentrations ranged from 33 to 2 pCi/L. The greatest conceritration was detected at Road $A 7$. Here the stream has not yet been diluted with the discharge water from C-Reactor. The lower concentrations observed at Highway 125 compared to Road A7 reflect the dilution by C-Reactor discharge.

Other Streams

Grab samples from streams (other than Four Mile Creek) feeding thie Savannah River were collected in August 1977 and June 1978 at the Highiay 125 crossing (Figure 1). Results are presented in Tatle VI. These concentrations did not exceed $0.002 \mathrm{pCi} / \mathrm{L}$. Thus, the major stream for transport of $1-129$ to the Savannah River is Four Mile Creek. The I-leg content of any plant stream is strongly diluted by the Savannah River. 


\author{
Savannat River \\ Grä 5 amples at upriver and downiver locetions have besa \\ intermittently collected since 1970. Results are shown in \\ Figures 5 arid 6 . The typical concentration at Shell 81 iff. \\ $5 \mathrm{miles}$ uprjver of the p?ant boundary, was less thail tie lisual \\ detection limit of $0.0003 \mathrm{pCi} / \mathrm{L}$. At Highway 301 Bridge, about \\ 20 miles downriver, the typical concentration was a factor of \\ 10 greater, namel' $0.003 \mathrm{pCi} / \mathrm{L}$. \\ Anomalous results at Shell Bluft occurred in monthly samples from \\ Mey through September 1978. During tiris time I-129 concertrations \\ at Stell Bluff were greater than 0.00l pCi/L. Furthermare, in May \\ and Jume the corcentration at Shell Bluff was essentially equal to \\ the cancentretion at Highway 301 Bridge. \\ The typical cownriver I-l29 coricentiation of o.003 plis/l. \\ represents $0.3 \%$ of the existing EPA drinking water standard \\ (j $p[\mathrm{i} / \mathrm{L}$ ) and $0.003 \%$ of the pending EPA standard ( $100 \mathrm{jCi} / \mathrm{L})$. \\ There are two downriver water treatment plants which process \\ Savarmah Piver water, namely, the Beaufort-Jasper hater ireatment \\ Plant ard the Port wentworth water Treatment Plant. \\ Concentrations at these plants have not yet been determined \\ (scheduled for this fiscal year), but they are estimated to be \\ less than or equal to the river concentrations at Highway 301 \\ Bridge.
}


Table I. I-129 Concentrations in Burial Ground Well Water

\begin{tabular}{|c|c|c|c|c|}
\hline \multicolumn{5}{|c|}{ Approximate } \\
\hline te 11 & Depth & $(\underline{t})$ & Datteㅡ & $\mathrm{e} E \mathrm{i} / \underline{\mathrm{L}}$ \\
\hline Fiesults & extracted & from & DPST $-86-278$ & \\
\hline$I-13$ & & & 1983 & 0.006 \\
\hline$B G L-3 C$ & & & 1983 & 0.92 \\
\hline$B G C-2 C$ & & & 1983 & 0.033 \\
\hline$B G-109$ & & & 1983 & 0.01 \\
\hline PDQS & & & Aug $>83$ & 12 \\
\hline PDOS & & & Dec $\cdot 82$ & 1.5 \\
\hline PDQS & & & $A p T^{\prime}=82$ & 0.25 \\
\hline Uther & udies & & & \\
\hline $8 G-57$ & 45 & & 1979 & $\begin{array}{l}0.0053 \\
\pm .0008\end{array}$ \\
\hline FG-56 & 47 & & 1980 & $\begin{array}{l}0.0074 \\
\pm .0008\end{array}$ \\
\hline
\end{tabular}


Table II. I-129 Concentrations in F-Area Effluent Stream

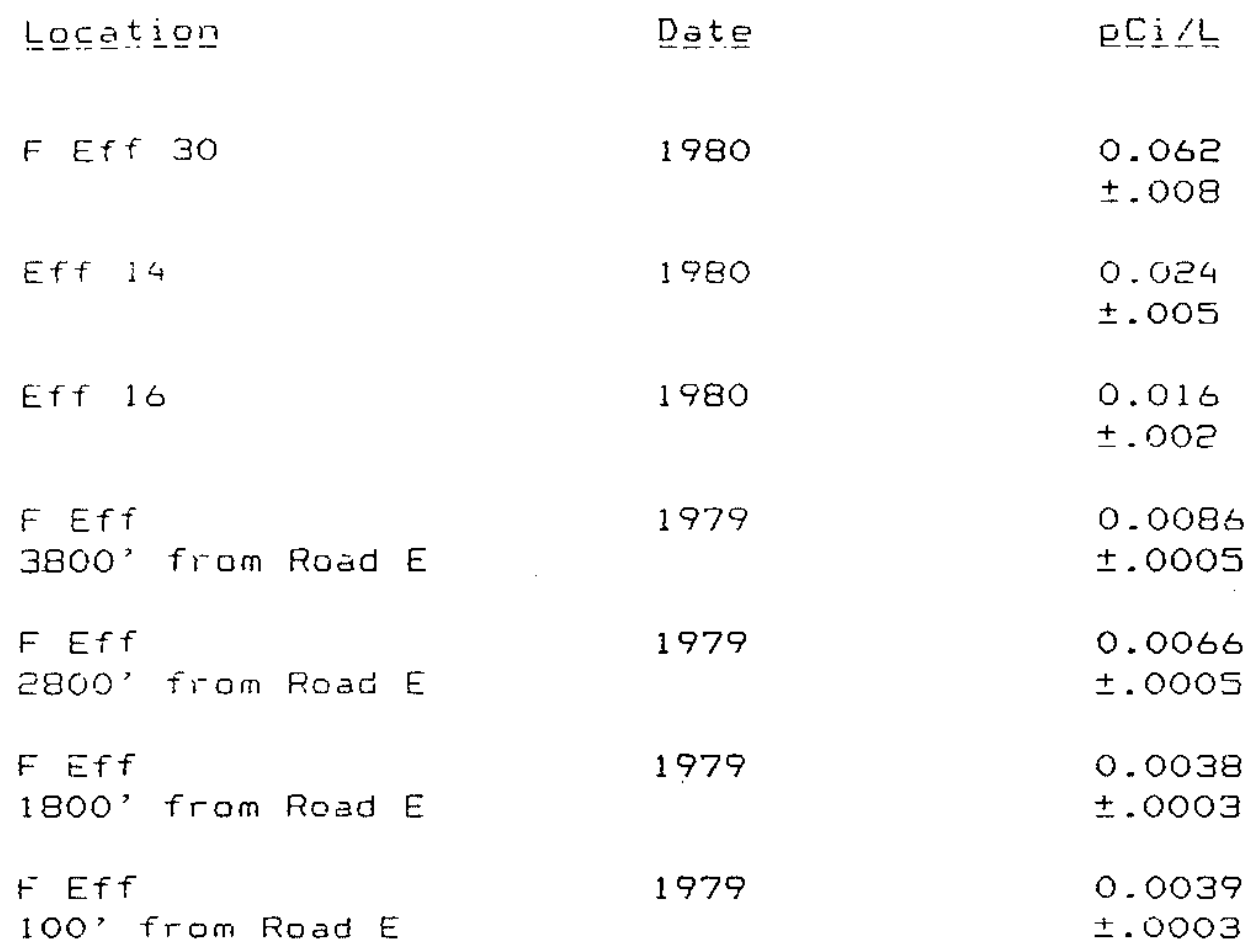


Table III. I-129 Concentrations in Separations Seepage Basins

$\underline{D} \overline{\underline{t}} \underline{\underline{e}}$

$$
\begin{array}{r}
8-77 \\
12-77 \\
1-78 \\
3-78 \\
4-78 \\
5-78 \\
6-78 \\
7-78 \\
8-78 \\
9-78 \\
10-78 \\
11-78 \\
12-78
\end{array}
$$

I-129 Concentration ( $\mathrm{pC} \mathrm{C} / \mathrm{L}$ )

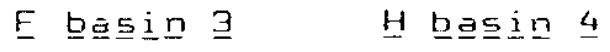

$$
\begin{array}{r}
140 \pm 4 \\
152 \pm 6 \\
54 \pm 3 \\
198 \pm 6 \\
143 \pm 5 \\
228 \pm 10 \\
189 \pm 9 \\
153 \pm 8 \\
208 \pm 10 \\
100 \pm 13 \\
77 \pm 3 \\
145 \pm 7 \\
299 \pm 10
\end{array}
$$


Table IV. I-129 Concentrations in Well Water Near Seepage Basins

$\underline{\text { We}} \underline{1} \underline{1}$

Deㅡ름 $(\underline{f} \underline{t} \underline{)}$

$\underline{I}=\underline{1} \underline{2} \underline{Q} \quad \mathrm{Q} \underline{\underline{1}} 1 \underline{\underline{L}}$

$\underline{H}-\underline{3} \underline{\underline{ }} \underline{\mathrm{i}} / \mathrm{L}$
1977 Sampling

H-Area

$\mathrm{H}-13$

$\mathrm{H}-1$ 4

$H-15$

H-1

$\mathrm{H}-19$

F-คre⿻

$F-15$

$F-16$

$\mathrm{F}-17$

$F-25$

1980 Sampling

H-Area

BG-10
35

35

35

35

35

55

60

45

55

20

4.4
16
0.083
0.14
0.61

1. 2

4.0

0.056

0.052

1. 9
0.13

ट2

0.021

0.75

0.091

0.87

$63 \pm 1$ 
Table V. I-129 Concentrations in Four Mile Creek

\begin{tabular}{|c|c|c|}
\hline 느므므므믐 & $\underline{D} \underline{\underline{t}} \underline{\underline{e}}$ & $\mathrm{Q} E \mathrm{i} / \mathrm{L}$ \\
\hline Ijpstream of Dutcrops from & F-Area Seepage & Basins \\
\hline $\begin{array}{l}\text { Retween Road } 4 \text { and } \\
F \text { basin outcrops }\end{array}$ & 1980 & $\begin{array}{l}1.06 \\
+ \text { - } 55\end{array}$ \\
\hline " & 1980 & $\begin{array}{l}0.46 \\
\pm .05\end{array}$ \\
\hline " & 1980 & $\begin{array}{l}1.01 \\
\pm .11\end{array}$ \\
\hline " & 1980 & $\begin{array}{l}1.19 \\
\pm .19\end{array}$ \\
\hline " & 1980 & $\begin{array}{l}0.86 \\
\pm .26\end{array}$ \\
\hline$"$ & 1979 & $\begin{array}{l}0.95 \\
\pm .02\end{array}$ \\
\hline " & 1979 & $\begin{array}{l}0.44 \\
\pm .01\end{array}$ \\
\hline$"$ & 1979 & $\begin{array}{l}0.146 \\
\pm .005\end{array}$ \\
\hline " & 1977 & 0.17 \\
\hline
\end{tabular}

$\begin{array}{lcc}\text { Downstream of Outcrop from F-Area Seepage Basins } \\ \text { Road A7 } & 8 / 77 & 1.7 \\ \text { Road A7 } & & \\ & 6 / 73 & 33.3 \\ \text { Hwy 125 } & & \pm 4.5 \\ \text { Hwy 125 } & 6 / 78 & 0.091 \\ & 8 / 77 & \pm .006 \\ & & 0.043 \\ & & \pm .002\end{array}$


Table VI. I-129 Concentrations in SRP Streams
(Other than Four Mile Creek)

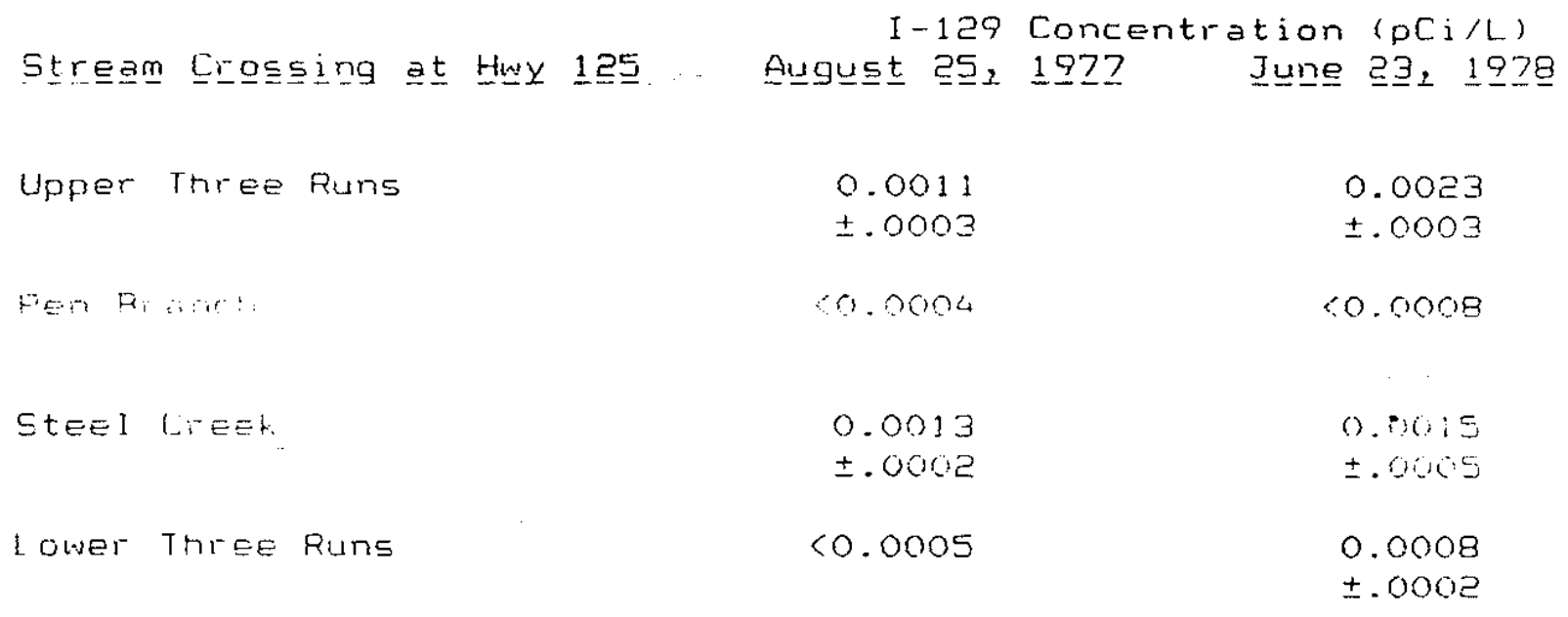


Figure 1. On-Plant and Off-Plant Sampling Locations. (Indicated by circled areas)

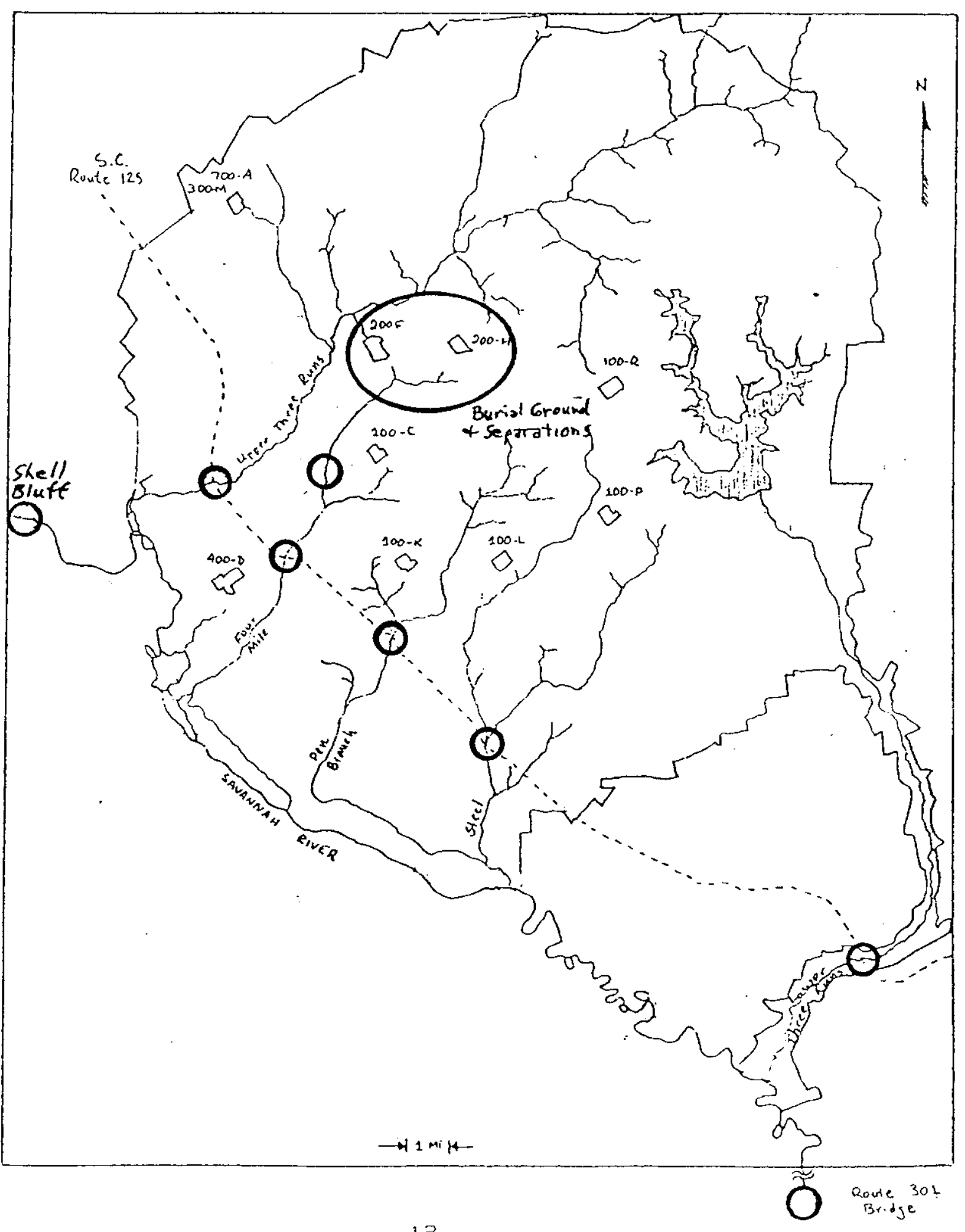


Figure 2. Location of Burial Ground Wells.
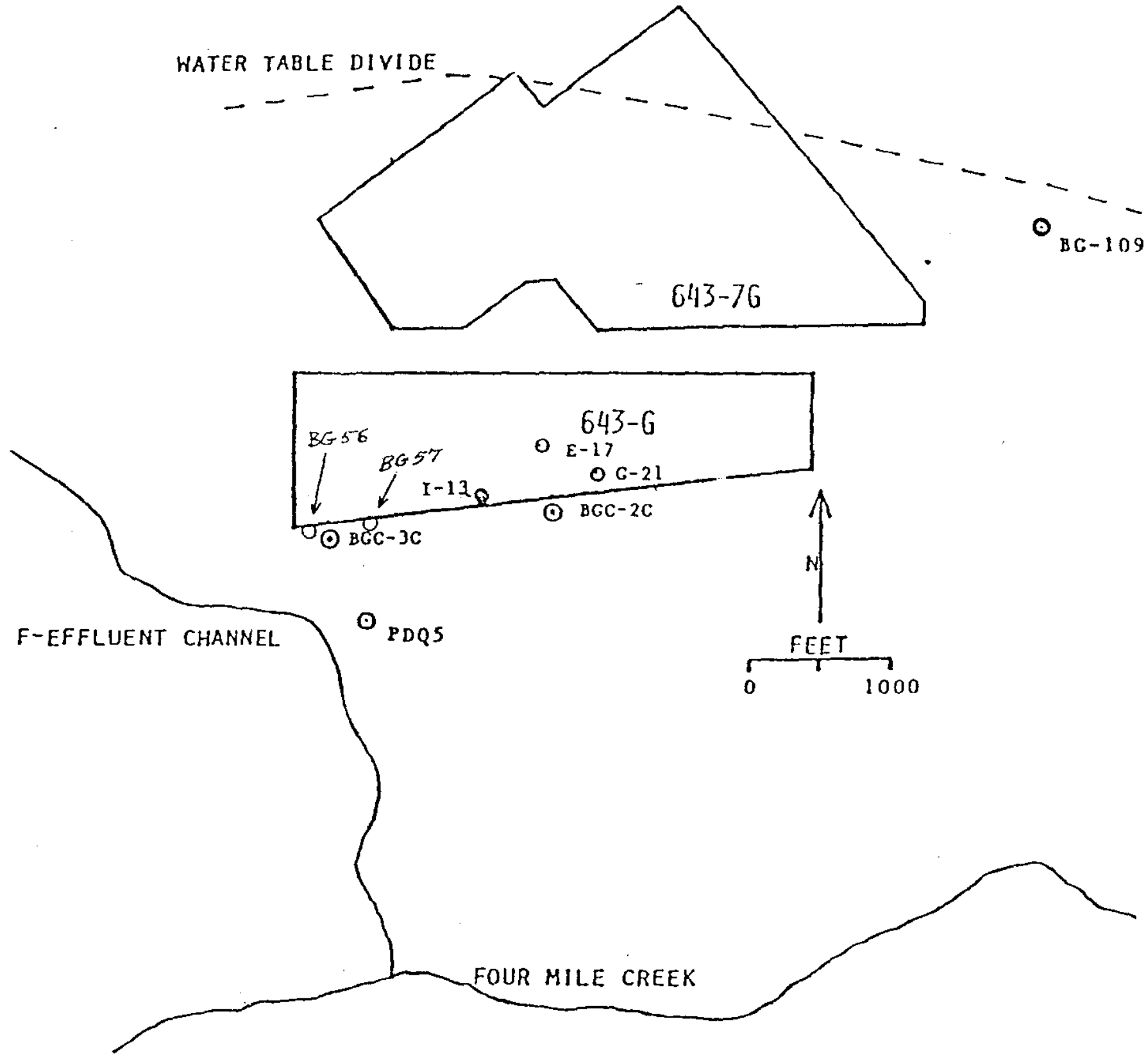
Figure 3. Location of H-Area Seepage Basins and Wells.

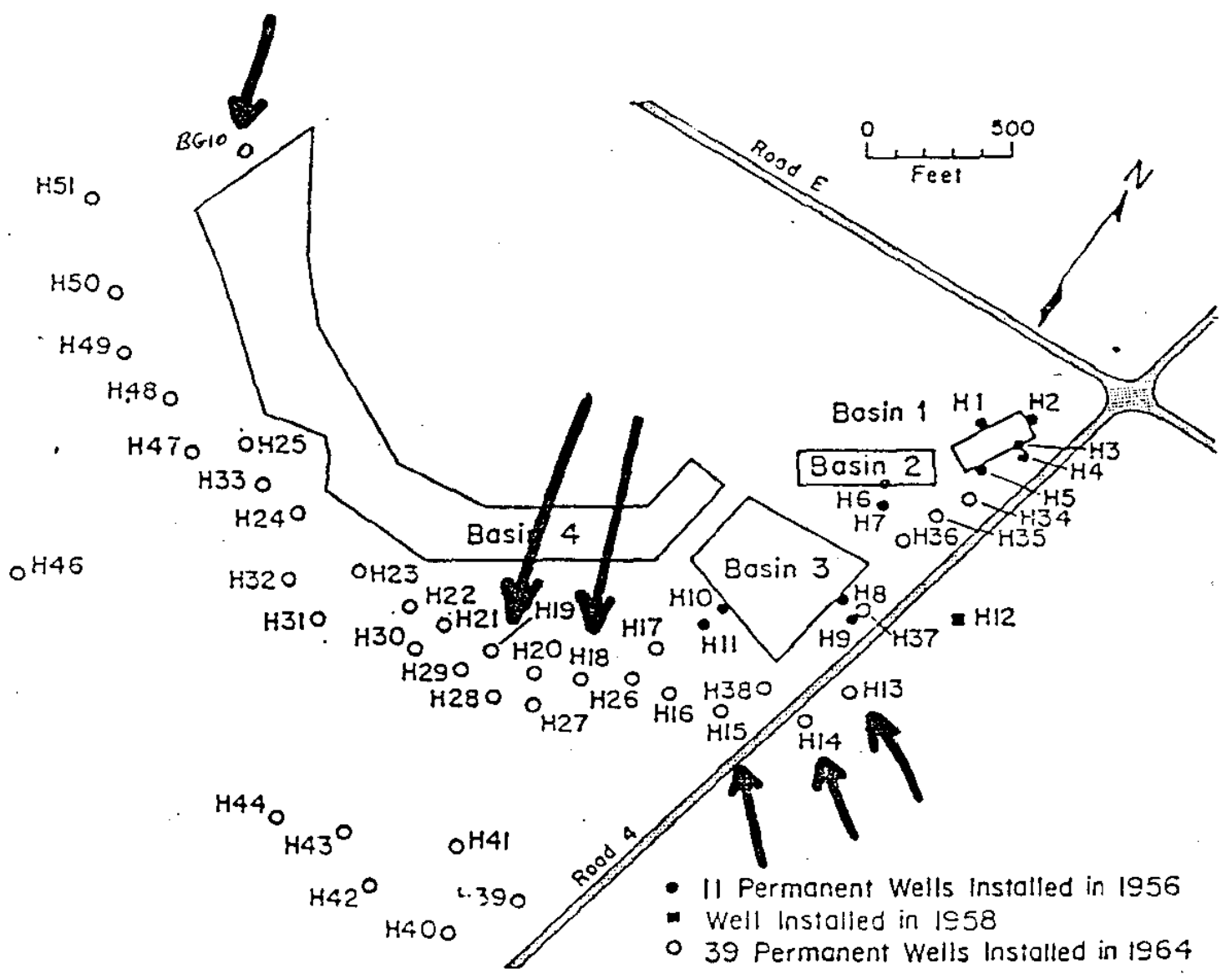


Figure 4. Location of F-Area Seepage Basins and Wells.

13 Permonent Wells installed in 1956

- Screened in Perched Woler

- Screened in Normal Water Table

- 9 Wells Installed in March 1962

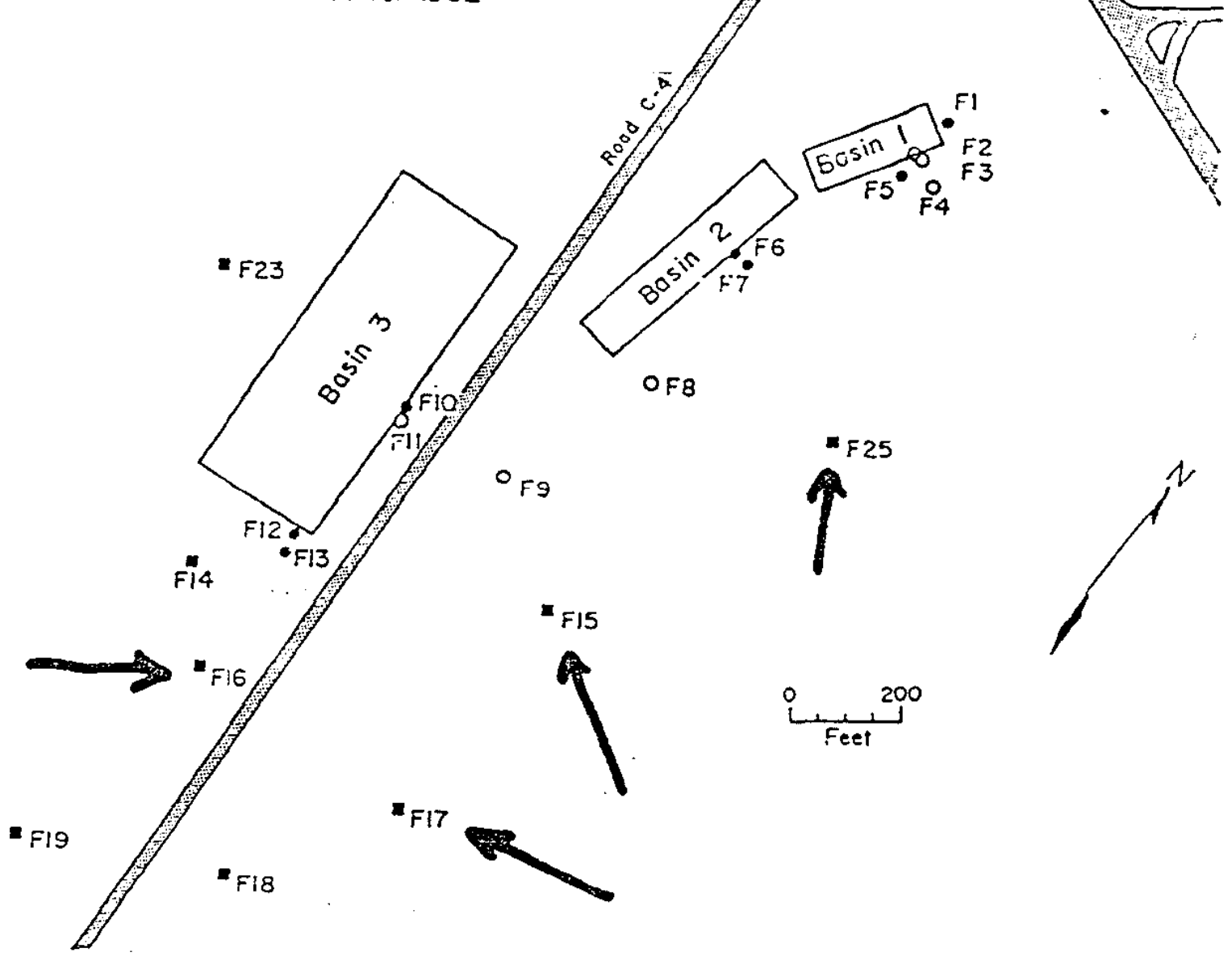


Figure 5. I-129 Concentrations in Savannah River at Shell Bluff.

1

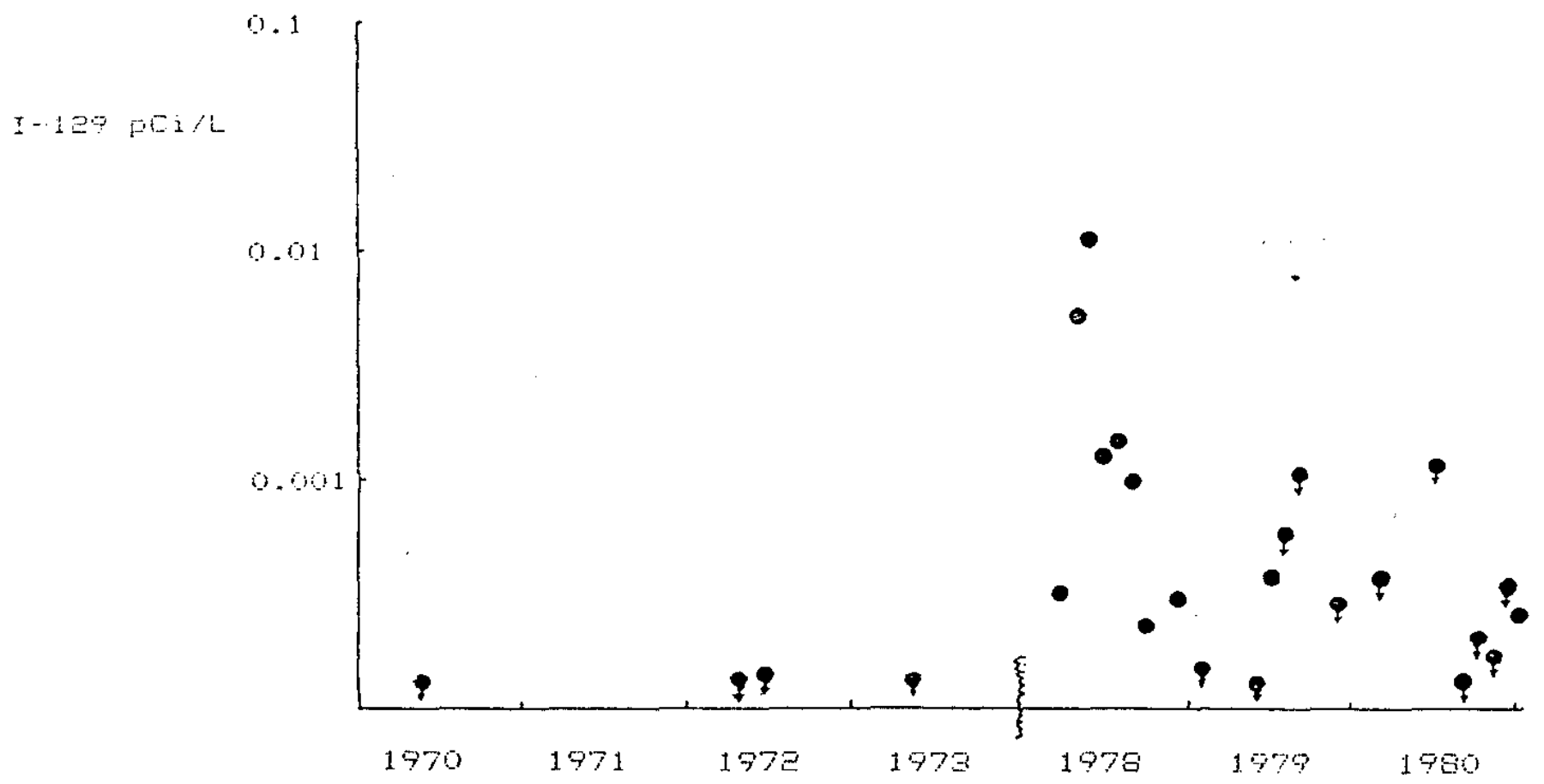

Note: An arrow on a data point indicates the detection

limit. The actual concentration of the sample is less than or equal to the plotted value. 
Figure 6. I-129 Concentrations in Savannah River at Highway 301 Bridge.

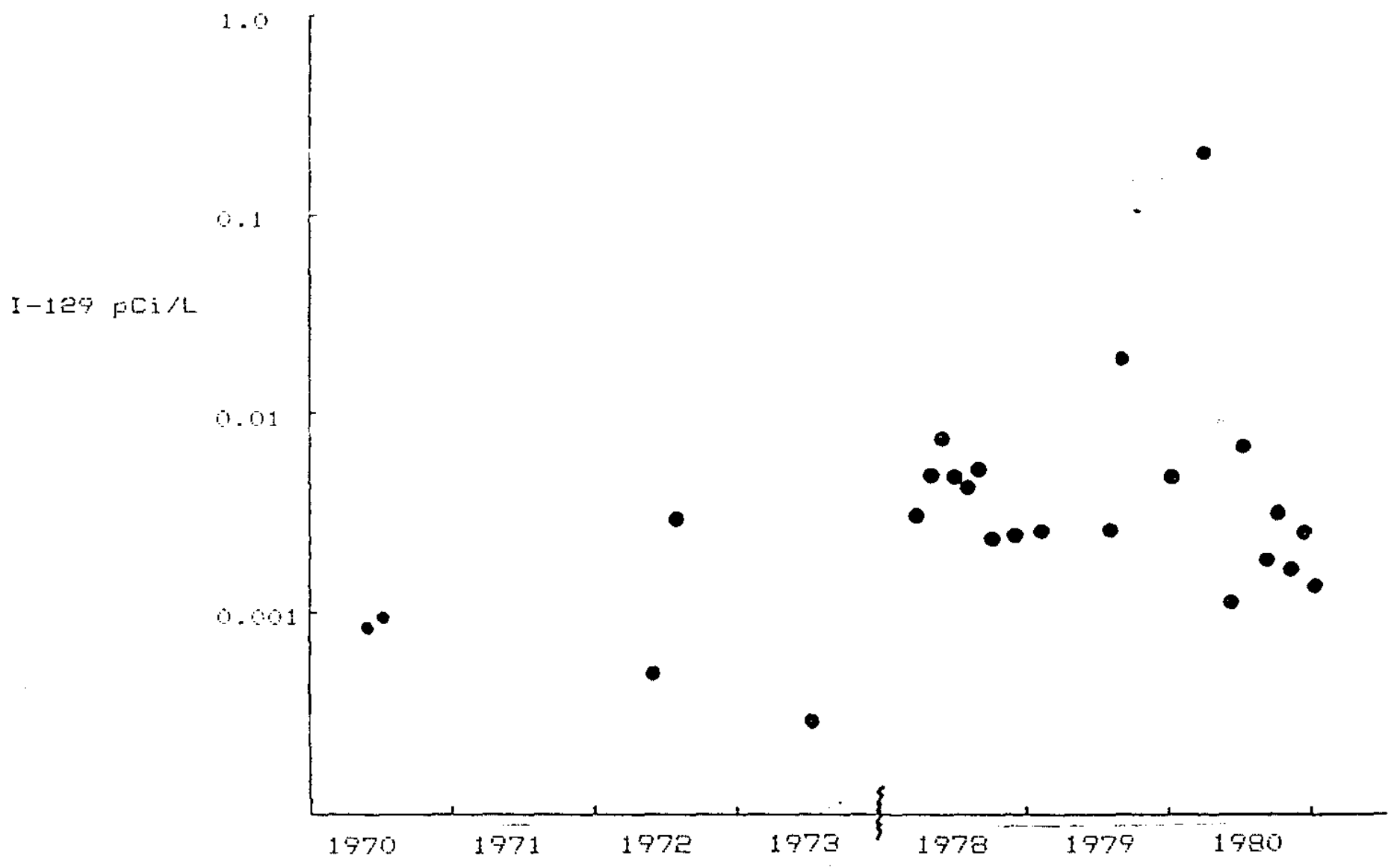

